\title{
THE RIGHT TO A FAIR TRIAL AND THE FREE MOVEMENT OF CIVIL JUDGMENTS
}

\begin{abstract}
Jan-Jaap Kuipers*
Summary: This paper analyses the role and function of the right to a fair trial in Brussels I. Particular emphasis will be placed on how the European Court of Justice balances the right to a fair trial against the free movement of judgments. This question will be answered in terms of whether the ECJ perceives the right to a fair trial to constitute an autonomous source of obligations or whether it interprets (and if so, how it does so) PIL mechanisms in the light of the requirements of a fair trial. In particular, the paper will analyse to what extent the courts in the Member State addressed may review compliance with the right to a fair hearing of the court originally seized. Finally, the proposal of the European Commission to abolish the exequatur will be examined from a fundamental rights perspective.
\end{abstract}

\section{Introduction}

The grounds for jurisdiction have traditionally differed widely between the Member States. It was recognised that the accomplishment of an internal market could only be achieved when adequate legal protection was ensured throughout the Union. ${ }^{1}$ Art 220 EEC therefore allowed Member States to enter into negotiations with each other with a view to securing for the benefit of their nationals the simplification of formalities governing the reciprocal recognition and enforcement of judgments of courts or tribunals. Recognition addresses the acceptance that the court of origin has validly determined the rights and obligations of the parties. Enforcement entails making the judgment effective. The creditor will have access to all enforcement remedies as if the judgment had been obtained in the Member State of recognition. Art 220 EEC resulted in the Brusse1s Convention on Jurisdiction and Enforcement of Judgments in Civil and Commercial Matters (1968). To further facilitate the working of the common market, the Convention also adopted uniform grounds of juris-

\footnotetext{
Jan-Jaap Kuipers is a PhD candidate at the European University Institute in Florence (Italy).

1 Report on the Convention on jurisdiction and the enforcement of judgments in civil and commercial matters (1979) Jenard Report, OJ C59 3.
} 
diction. In an additional protocol, the European Court of Justice (ECJ) was awarded the power of interpretation. ${ }^{2}$

Following the conferral of powers upon the Community to act in the area of PIL in the Amsterdam Treaty, ${ }^{3}$ the Brussels Convention was transformed into the Brussels I Regulation on Jurisdiction and the Recognition and Enforcement of Judgments in Civil and Commercial Matters (44/2001). Despite several problematic areas, ${ }^{4}$ the functioning of Brussels I is generally satisfactory. In April 2009, the Commission launched a Green Paper for the revision of Brussels I in order to trigger broad consultation among interested parties on possible ways to improve the operation of the Regulation. ${ }^{5}$

The general rule of Brussels I is that a person shall be sued in the courts of the Member State where he is domiciled. Special rules on jurisdiction are available for specific types of actions. For example, an action relating to a tort can be brought in the courts of the Member State where the damage occurred, or, in an action involving a number of defendants, the defendant could be sued in the courts of the place where any one of them is domiciled. Moreover, a number of exclusive jurisdiction rules deviate from the main rule. An example is that proceedings relating to a right in rem in an immovable property are to be brought in the courts of the country where the immovable is situated. The uniform grounds of jurisdiction prevent courts from assuming exorbitant jurisdiction which facilitates the mutual trust between the courts of the Member States. The mutual trust, as well as the legal certainty that Brussels I aims to promote, justify only a limited review of judgments rendered by a court in another Member State.

2 Protocol concerning the interpretation by the Court of Justice of the convention of 27 September 1968 on jurisdiction and the enforcement of judgments in civil and commercial matters (signed in Luxembourg on 3 June 1971) [1975] OJ L 20428.

3 Art 65 EC replaced two articles adopted in 1991 on judicial co-operation in civil matters providing for the legal basis for the negotiation and adoption of PIL conventions in Title VI of the EU Treaty. On the gradual transformation of EU competences and influence of Union law upon PIL, see K Boele-Woelki, 'Unification and Harmonization of Private International Law in Europe' in J Basedow and others (eds), Private Law in the International Arena: Liber Amicorum Kurt Siehr (TMC Asser Press, The Hague 2000) 61-78; J Basedow, 'The Communitarisation of the Conflict of Laws under the Treaty of Amsterdam' (2000) 37 (3) CML Rev; M Bogdan, Concise Introduction to EU Private International Law (Europa Law Publishing, Groningen 2006) 6-14.

4 T Hartley, 'The European Union and the Systematic Dismantling of the Common Law of Conflict of Laws' (2005) 54 ICLQ 813-828; J Harris 'Understanding the English Response to the Europeanisation of Private International Law'(2008) 4 (3) Journal of Private International Law 347-395.

5 Green Paper on the Review of Council Regulation (EC) No 44/2001 on Jurisdiction and the Recognition and Enforcement of Judgments in Civil and Commercial Matters COM (2009) 175 final. 
The special rules on jurisdiction create the possibility that a defendant is not sued in the courts where he is domiciled. An example is a Finnish tourist causing a traffic accident in Sweden. The place where the damage has occurred does not coincide with the place where the defendant is domiciled. A defendant may therefore have to travel to another Member State to represent himself in court. This will not always be possible, or the defendant may not even be aware that legal proceedings against him have commenced in that other Member State. If a judgment is awarded against the defendant and if we assume that most of his assets will be located in the Member State where he is domiciled, the judgment still has to be enforced in that Member State. The purpose of this paper is to analyse the role and function of the right to a fair trial in Brussels I. First, the core features of the Brussels I system will be explained. Then, an assessment will be made of how the European Court of Justice balances the right to a fair trial against the free movement of judgments. Does the ECJ perceive the right to a fair trial to constitute an autonomous source of obligations or does the Court interpret (and if so, how does it do so?) the PIL mechanisms in the light of the requirements of a fair trial? In particular, to what extent may the courts in the Member State addressed review compliance with the right to a fair hearing of the court originally seized? Finally, the proposal of the European Commission to abolish the exequatur will be analysed from a fundamental rights perspective.

\section{The right to a fair trial}

Brussels I is a specific implementation of the area of freedom, security and justice which is ultimately aimed at guaranteeing legal protection to European citizens. The instrument in itself therefore already contributes to safeguarding the right to an effective judicial remedy. ${ }^{6}$ However, Brussels I needs to reconcile different interests. Art 36 Brussels I expressly provides that under no circumstances may a foreign decision be reviewed as to its substance. Strict prohibition is necessary from the perspective of a common European justice area. In order to promote the smooth circulation of judgments, a judgment should be challenged in the Member State of origin. Review as to the merits of the judgment would de facto create another possibility of appeal. A court may thus not verify whether the court in the Member State of origin has succeeded in striking a fair balance in, for example, the protection of the freedom of expression

\footnotetext{
6 A Borrás, 'Le droit international privé communautaire: réalités, problèmes et perspectives d'avenir' (2005) 317 Recueil des Cours 323-526. K Lenaerts, 'The Contribution of the European Court of Justice to the Area of Freedom, Security and Justice' (2010) 59 (2) ICLQ 255-301.
} 
or whether it took due account of the right to family life. ${ }^{7}$ Review should not be directed at assessing whether the original court made the 'right' decision, but whether the defendant was afforded an effective possibility to persuade the original court of his point of view. The role that the ECHR could play is therefore primarily limited to the procedure.

In essence, the regime for the recognition and enforcement of foreign judgments aims to strike a balance between the protection of the rights of defence and facilitation of the free movement of judgments within the common European justice area. In the words of AG Kokott:

The procedure for authorising enforcement forms part of an overall system established by the (Brussels, JJK) Convention which seeks to strike a balance between the free movement of judgments in civil and commercial cases and the protection of the rights of the defence. The rights of defence of the party against whom enforcement is sought are protected by the general principle of Community law recognised by the Court that everyone is entitled to fair legal process. This principle is guided by Article 6 of the ECHR and is reflected in Article 47 of the Charter of Fundamental Rights of the European Union. ${ }^{8}$

The ECJ thus draws particular inspiration from art 6 ECHR. An analysis of the precise protection afforded under this provision to individuals is beyond the scope of this paper. ${ }^{9}$ It will be preferred to make specific references to the case law of the European Court of Human Rights (ECtHR) whenever this appears to be useful. The ECtHR has pronounced itself on several occasions on recognition and enforcement proceedings. In $K v$ Italy, the ECtHR found Italy in breach of its obligations under the Convention because it failed within a reasonable period of time to render a decision on the enforcement of a Polish maintenance judgment. ${ }^{10}$ Recognition and enforcement proceedings thus are also bound to comply with the fair trial standards.

\footnotetext{
In extreme cases the recognition or enforcement of a decision may violate public policy. That could occur in cases of flagrant violation of a substantive fundamental right. The author has not been able to retrieve, with the exception of the right to a fair trial, any cases refusing the enforcement of a judgment on the basis of a substantive fundamental right.

8 AG Kokott in case C-3/05 Verdoliva [2006] ECR I-1579, para 39.

9 See P van Dijk and others (eds), Theory and Practice of the European Convention on Human Rights ( $4^{\text {th }}$ edn, Intersentia, Antwerp 2006) 511-650; R Grote and T Marauhn (eds), EMRK/GG: Konkordanzkommentar zum europäischen und deutschen Grundrechtschutz (Mohr Siebeck, Tübingen 2006) 642-719; M Janis and others (eds), European Human Rights Law: Text and Materials ( $3^{\text {rd }}$ edn, OUP 2008) 718-826; K Reid, A Practitioner's Guide to the European Convention on Human Rights ( $3^{\text {rd }}$ edn, Sweet and Maxwell, London 2008), 63214; D Harris and others (eds), Law of the European Convention on Human Rights ( $2^{\text {nd }}$ edn, OUP) 201-330.

10 K v Italy (App no 38805/97) ECHR 2004-VIII.
} 
In Pelligrini, a husband initiated proceedings for the annulment of a marriage before the ecclesiastical courts of the Holy See. ${ }^{11}$ The wife was only informed of the content of the action when she appeared before the court and, moreover, the ecclesiastical court had not informed the wife of her right to legal representation. A judgment was awarded in favour of the husband, of which he subsequently sought recognition in Italy. Italy was found to be in breach of its obligations under art 6 because it failed to verify the compliance of the proceedings in the court of origin with the guarantees of art 6. The ECtHR appears to have departed in Pelligrini from its main rule that the Convention can only trigger the responsibility of Contracting Parties for acts committed in a non-Contracting Party in the case of a flagrant violation of the Convention. ${ }^{12}$ The reasoning of the ECtHR implies that the right to a fair trial is an autonomous source of obligations, imposing an obligation for Contracting States to refuse a judgment handed down in violation of the right to a fair trial, rather than that the principle guides the interpretation of traditional PIL notions, such as public policy, in the light of fair trial standards.

Pelligrini is a dangerous decision. In particular, one wonders whether in all circumstances the failure of a state to guarantee the right to a fair trial to an individual can stand in the way of the recognition of the subsequent decision in a dispute between two private parties. ${ }^{13}$ Should the husband in Pelligrini have insisted that the wife be properly notified and represented in court, or could he have relied for that purpose upon the procedural law of the Holy See? Adversarial proceedings require that each party acts in what it perceives to be its best interest and there is no general duty of charity. The obligation of Italy not to recognise a judgment impedes the rights of the husband who might not have been under an obligation, or even in a position, to safeguard the rights of defence of his wife. It might have been better to leave the question of enforcement to the public policy of the Contracting States, as inspired by the requirements of art 6.

\footnotetext{
11 Pellegrini $v$ Italy (App no 30882/96) ECHR 2001-VIII.

12 Soering $v$ United Kingdom (App no 14038/88) ECHR 7 July 1989); Drozd and Janousek $v$ France and Spain (App no 12747/87) ECHR 26 June 1992; Bader v Sweden (App no 13284/04) ECHR 8 November 2005; Mamatkulov v Turkey (2005) (App no 46827/99 and 46951/99) ECHR 4 February 2005; Maumousseau and Washington v France (App no 39388/05) ECHR 6 December 2007.

13 The values enshrined in the Convention may be common to the Contracting Parties, but are not necessarily universal. The international harmony of decisions, legal pluralism and mutual tolerance require restraint with the pursuance of 'home values' on the international level. In PIL this is referred to as 'relativisme des valeurs'. See L Gannage, 'L'ordre public international a l'épreuve du relativisme des valeurs (2009) Travaux du comité Français de Droit International Privé 2006-2008, 205-241.
} 
It is therefore not surprising that national courts have sought to distinguish Pelligrini. ${ }^{14}$ Pelligrini concerned a judgment from a non-Contracting State. A presumption that a judgment complies with art 6 will exist when the judgment originates from another Contracting State. ${ }^{15}$ Moreover, contrary to violations in a non-Contracting State, an individual has the possibility to seek redress against the violation of art 6 in the original procedure by means of launching an individual complaint before the ECtHR. It thus appears that Pelligrini is limited to judgments from non-Contracting States. ${ }^{16}$

\section{The duty to recognise in Brussels I}

From the perspective of Brussels I, a distinction should be drawn on the basis of whether or not the original judgment is pronounced in a Member State of the Union. Brussels I can only confer jurisdiction upon a court established in a Member State. Whenever the defendant is not domiciled in one of the Member States, Brussels I is not applicable. ${ }^{17} \mathrm{Ju}-$ risdiction in disputes involving a defendant not domiciled in one of the Member States can resort from international conventions concluded by the Union ${ }^{18}$ or from national law. Similarly, the duty to recognise a foreign decision is limited to judgments rendered in another Member State. The recognition of judgments coming from a third country is left to be governed by international conventions and national law. The decision to recognise a third country judgment in a Member State does not affect the

\footnotetext{
14 English courts have distinguished Pelligrini through the specific relationship between the Holy See and Italy governed by a concordat. The Pelligrini rule was therefore limited to the factual circumstances of that specific case. See critically J Fawcett, 'The Impact of Art. 6 (1) of the ECHR on Private International Law' (2007) 56 ICLQ 1, 23.

15 P Kinsch, The Impact of Human Rights on the Application of Foreign Law and on the Recognition of Foreign Judgments: A Survey of the Cases Decided by the European Human Rights Institutions' in T Einhorn and K Siehr (eds), International Cooperation Through Private International Law: Essays in Memory of Peter E. Nygh (TMC Asser Press, The Hague 2004) 197-228; and more elaborately P Kinsch, 'Droits de l'homme, droits fondamentaux et droit international privé' (2005) 318 Recueil des Cours 19, 325.

16 For a contrary view, see B Juratowitch, 'The European Convention on Human Rights and English Private International Law' (2007) 3 (1) Journal of Private International Law 173-199. Juratowitch focuses on the independent responsibility of the state responsible for the act of facilitating or ratifying a breach of ECHR standards. From this perspective it does not matter whether a state is a contracting party or not since what is considered is the conduct of the state giving effect to the breach. The test on compliance proposed by Juratowitch is not confined to flagrant violations.

17 Save for arts 22 and 23 dealing with the grounds for exclusive jurisdiction and the choice of court.

$18 \mathrm{~J}$ Kuipers, The Exclusive Competence of the Union under art. 81 TFEU: Lugano reopened?' in M Cremona, J Monar and S Poli (eds), The External Dimension of the Area of Freedom Security and Justice (forthcoming).
} 
recognition of the identical decision in another Member State. Exequatur sur exequatur ne vaut. Contrary to the free movement of goods, where an imported good benefits from free circulation as soon as it has lawfully entered a Member State, there is no free circulation of judgments. The decision of Italy to recognise or not a decision from Saint Vincent and the Grenadines did not in any way affect the position of a UK court. ${ }^{19}$ Any refusal to recognise or enforce a judgment pronounced in a third country will therefore not conflict with the system established by Brussels I, since third country judgments do a priori not benefit from the free circulation of judgments.

The Pelligrini obligation to verify the compliance of the court of origin with the right to a fair trial does therefore not conflict with the free movement of judgments under Brussels I. Every Member State of the European Union is a Contracting Party to the ECHR. Judgments from non-Contracting Parties to the ECHR are outside the system of facilitated recognition of Brussels I. The question, however, remains whether a judgment that raises fair trial concerns could be liable for recognition under the system of Brussels I. Of importance is that the construction of what a Member State considers to be its public policy is no longer a strictly unilateral exercise. The Union seems to develop a core of rules that will enter the notion of public policy in the Member States. Fundamental rights could become part of that EU public policy. On the other hand, an obligation to refuse to recognise a decision that violates art 6 ECHR may conflict with the free circulation of judgments within the Union as protected by Brussels I.

Let us first focus on the concept of the free movement of judgments. The core of the free movement of judgments are articles 33 and 38 Brussels I. Art 33 (1) provides that 'a judgment given in a Member State shall be recognised in the other Member States without any special procedure being required', and art 38 (1) determines that a 'judgment given in a Member State and enforceable in that State shall be enforced in another Member State when, on the application of any interested party, it has been declared enforceable there'. ${ }^{20}$ The effects of the judgment are not

\footnotetext{
19 Case C-129/92 Owens Bank Ltd v Fulvio Bracco [1994] ECR I-117.

20 P Kaye, Civil Jurisdiction and Enforcement of Foreign Judgments (Professional Books Limited, Abingdon 1987); J Kropholler, 'Europäisches Zivilprozeßrecht (7. Auflage, Verlag Recht und Wirtschaft, Heidelberg 2001); E Pataut, 'L'exécution des jugements nationaux et la convention de Bruxelles' in Université Jean Moulin Lyon 3, Faculté de Droit, Centre d'Etudes Européennes (ed), Les effets des jugements nationaux dans les autres États membres de l'Union européenne (Bruylant, Brussels 2001) 31-53; S Carbone, Lo spazio giudizaiario europeo in material civile e commercial: Da Bruxelles I al regolamento CE $n$. 805/2004' (G Giappichelli Editore, Torino 2006) 227-297; U Magnus and P Mankowski (eds), Brussels I Regulation (Sellier, München 2007); M Berglund, Cross-Border Enforcement of Claims in the EU: History, Present Time and Future (Kluwer Law International, Deventer 2009).
} 
determined by the recognising court, but by the country of origin. ${ }^{21}$ There is no requirement that the judgment should be final or conclusive. Provisional and protective measures are also covered. It is sufficient that a judgment is provisionally enforceable in the Member State of origin, even when the judgment is still open to appeal..$^{22}$ Equally, it does not matter whether jurisdiction is assumed on the basis of Brussels I. Even if the national court assumed jurisdiction upon the basis of a national rule, the recognition and enforcement of that decision falls within the scope of Brussels I. ${ }^{23}$

A judgment from a Member State does not have automatic legal force in other Member States. An application of an interested party for the enforcement of the original judgment is required. The judgment of the recognising court granting enforcement is referred to as an exequatur. The exequatur shall be granted upon a copy of the judgment which satisfies the conditions necessary to establish its authenticity (art 41). The decision concerning the grant of an exequatur may be appealed by either party. It is only on appeal that the recognising court may test the original judgment. The accelerated exequatur procedure is rather efficient, since only between $1-5 \%$ of the declarations on enforceability are appealed. ${ }^{24}$ An exequatur can only be refused or revoked for the reasons provided for in Brussels I. Art 45 refers back to the grounds to refuse to recognise the original judgment. Art 34 provides:25

A judgment shall not be recognised:

1. if such recognition is manifestly contrary to public policy in the Member State in which recognition is sought;

21 Case 145/86 Hoffmann v Krieg [1987] ECR 645.

22 Under art 37 and 46 the court before which recognition and enforcement is sought may stay the proceedings if an actual appeal against the original judgment has been lodged.

23 Note, however, that the general limitation in the scope of Brussels I is still applicable. A judgment should therefore fall within the scope of art 1. Joined Cases 9 and 10/77 Bavaria Fluggesellschaft $v$ Eurocontrol [1977] ECR 1517.

24 B Hess, T Pfeiffer and P Schlosser, The Brussels I Regulation: Application and Enforcement in the EU (Verlag CH Beck, München 2008) 127. The exequatur procedure is accelerated because outside the framework of Brussels I exequatur is considered in contradictory proceedings.

25 The forerunner of art 34, art. 27 Brussels Convention, contained another ground: if the court of the State of origin, in order to arrive at its judgment, has decided a preliminary question concerning the status or legal capacity of natural persons, rights in property arising out of a matrimonial relationship, wills or succession in a way that conflicts with a rule of the private international law of the State in which the recognition is sought, unless the same result would have been reached by the application of the rules of private international law of that State'. That ground has been abolished in the light of the unification of the conflict of law rules by the Union and the accompanying power of interpretation of the ECJ. 
2. where it was given in default of appearance, if the defendant was not served with the document which instituted the proceedings or with an equivalent document in sufficient time and in such a way as to enable him to arrange for his defence, unless the defendant failed to commence proceedings to challenge the judgment when it was possible for him to do so;

3. if it is irreconcilable with a judgment given in a dispute between the same parties in the Member State in which recognition is sought;

4. if it is irreconcilable with an earlier judgment given in another Member State or in a third State involving the same cause of action and between the same parties, provided that the earlier judgment fulfils the conditions necessary for its recognition in the Member State addressed.

The reasons for refusal are in principle exhaustive. However, the recognising court remains bound by limitations imposed by public international law. If, for example, state immunity was not respected in the court of origin, the resulting judgment would not be entitled to recognition in other Member States. ${ }^{26}$ A more elegant solution is available. Questions involving the immunity of foreign powers will most often fall outside the scope of Brussels I. Hence, civil matters did not cover a legal action brought by natural persons in Greece against Germany for compensation in respect of the loss or damage suffered by the successors of the victims of acts perpetrated by German armed forces during the Second World War in Greece. ${ }^{27}$

With regard to the grounds provided for by art 34, of particular importance is that, with the limited exception of jurisdiction relating to insurance and consumer contracts and exclusive grounds for jurisdiction, the jurisdiction of the court of the Member State of origin may not be reviewed (art 35). The assumption is that a court of one Member State is never in a better position to determine whether the court of another Member State has jurisdiction than the original court itself. ${ }^{28} \mathrm{~A}$ court may thus

\footnotetext{
26 Magnus \& Mankowski (n 20) 559.

27 Case C-292/05 Lechouritou [2007] ECR 1519. See also: Apcios Пáyos (Greek Civil Supreme Court) 1 October 2007, 1857/2007 holding that the structure of Brussels I which prevented its application in respect of acts of sovereign states that did not fall into its regime was not contrary to the rules of public international law. In this respect, it must also be noted that the Court of Appeals of The Hague held that the award of immunity to the United Nations for allegedly negligent conduct surrounding the genocide in Srebrenica did not breach art 6 EHRM since the applicants could still pursue their claim against either the Dutch State in the Netherlands (the applicants alleged similar negligent conduct on the part of the Dutch State) or the perpetrators of the genocide. Gerechtshof 's-Gravenhage (30 March 2010) LJN BL8979.

28 Case C-351/89 Overseas Union Insurance and Others [1991] ECR I-3317, para 23; Case C-185/07 West Tankers [2009] ECR I-0000, para 29.
} 
not refuse to recognise a decision on the grounds that the original court misapplied Brussels I and was not competent to hear the case.

The third and fourth grounds for refusal do not raise any particular fundamental rights issues. These grounds relate to the smooth functioning of a common European Justice Area rather than the protection of individual parties. They deal with the possibility of irreconcilable judgments within the Union. Two judgments are irreconcilable if they entail legal consequences that are mutually exclusive. ${ }^{29}$ The recognising court will give priority to a judgment pronounced in its own jurisdiction, while in the case of two conflicting foreign judgments with the same cause of action, priority is awarded to the judgment that was rendered earlier. The risk of conflicting judgments having legal force in a Member State is for a large part already avoided at an earlier stage in the proceedings. A court is required to stay proceedings when a case involving the same cause of action and between the same parties has already been brought in the courts of another Member State (lis pendens). ${ }^{30}$ An additional mechanism might be suitable for the situation where a court is not aware of foreign proceedings, a situation that might especially arise in default proceedings. Moreover, art 34 (3) and (4) are wider than the lis pendens rule because the provisions also cover disputes outside the scope of Brussels I. ${ }^{31}$ In addition, sub (4) allows a court to refuse recognition on the grounds of irreconcilability with an earlier judgment from a third country that fulfils all the conditions for recognition in the Member State before which court recognition has been sought.

\section{Brussels I and the right to a fair trial}

Before assessing the possibility of refusing to recognise or enforce a foreign decision on the grounds of the non-observation of fair trial standards, it should be observed that the right to a fair trial is not only guaranteed via the possibility to refuse to recognise or enforce a foreign decision, but is interwoven in the doctrinal framework of Brussels I. Whereas the ECtHR leaves it primarily upon national law to define whether a tribunal is established by law and fulfils the characteristics

\footnotetext{
29 Case 145/86 Hoffmann v Krieg [1988] ECR 645, para 22.

30 Art 27 Brussels I. The avoidance of risk of conflicting judgments also means that a party in whose favour a judgment is rendered cannot commence fresh proceedings in another Member State instead of requesting an exequatur, even if fresh proceedings would entail less procedural costs. Case 42/76 De Wolfv Harry Cox [1976] ECR 1759.

31 The situation of conflicting judgments could, for example, arise when an action is declared civil in one Member State, but criminal in the other. See Înalta Curte de Casație şi Justiție a României (Romanian Supreme Court) (3 May 2007) 3542/2007.
} 
of a court, ${ }^{32}$ the ECJ has developed, via an autonomous interpretation of the notion 'judgment', requirements regarding the characteristics of the court. From the outset, it must be observed that Brussels I does not contain a definition of what constitutes a court or tribunal. However, in Solo Kleinmotoren, the ECJ held that for a judicial decision to be a judgment for the purposes of Brussels I, the decision in question must emanate from a judicial body of a Member State deciding on its own authority on the issues between the parties. 33 Where the ECtHR would have found a violation of the standards of art 6 ECHR when, for example, the Sofia City Court was bound to follow the assessment of the Bulgarian National Bank concerning the solvability of a bank in the context of bankruptcy proceedings,$^{34}$ the ECJ would probably have held that the decision fell outside the framework of Brussels ${ }^{35}$ because the Sofia City Court did not decide the case on its own authority. It has been argued that an English default judgment would also fall outside the scope of Brussels I since under English law the plaintiffs' claim would be accepted by the English court without any further examination. ${ }^{36}$ In this interpretation, the requirements of independence and due process are read into the definition of judgment. However, Solo Kleinmotoren could also be read more restrictively. Brussels I does not apply to a settlement merely recorded by the court, since a settlement depends on the intention of the parties and not of the court. This would not apply to a default claim, ${ }^{37}$ even if the court does not enter into a substantive examination, since that does not deprive the judgment of its character and becomes a mere recording of the parties' intention. ${ }^{38}$ The ECJ has recently clarified in Gambazzi that the latter position prevails. ${ }^{39}$

32 Terra Woningen BV v The Netherlands (App no 20641/92) ECHR 1996; Chevrol v. France (App no 49636/99) ECHR 2003; Chaudet v France (2009) (App no 49037/06) ECHR 2009.

33 Case C-414/92 Solo Kleinmotoren [1994] ECR I-2237, para 17.

34 Capital Bank v Bulgaria (App no 49429/99) ECHR 2006.

35 Note that the decision, because it relates to bankruptcy, would already fall outside the ratione materiae of Brussels I (art 1 (2b)).

36 G Cuniberti, 'Annotation to Cour de Cassation 17 November 1999' (2000) 89 Revue Critique de Droit International Privé 786-792; A Layton and H Mercer (eds), European Civil Practice ( $2^{\text {nd }}$ edn, Sweet and Maxwell, London 2004) para 25.005.

37 French Cour de Cassation 17 November 1999. A French defendant was confronted with a writ of summons which was followed by a default judgment. The $\mathrm{CdC}$ refused to enforce the writ of summons, but implied it would have been willing to enforce the English default judgment. See Cuniberti (n 36) 786-792.

38 AG Kokott in Case C-394/07 Gambazzi [2009] ECR I-0000, paras 26 and 27.

39 Case C-394/07 Gambazzi [2009] ECR I-0000, para 25. See G Cuniberti, 'La reconnaissance en France des jugements par défaut anglais (à propos de l'affaire Gambazzi-Stolzenberg)' (2009) 98 (4) Revue Critique de Droit International Privé 685-714; G Cuniberti, 'Debarment from Defending : Default Judgments and Public Policy' (2010) (30 (2) IPRax 148-153. 
The ECJ held in Denilauler that a judgment relating to provisional and protective measures fell outside the scope of the Brussels I regime insofar as it was delivered without the summoning of that party against which the measures had been awarded and where the measures were intended to be enforced without prior service. ${ }^{40}$ The case concerned a French order to freeze a bank account of the debtor held in Frankfurt am Main. Under French law, such a seizing order was possible without the prior service of documents initiating the legal action on the debtor. The ECJ held that the liberal regime of recognition and enforcement was only possible because of the protection afforded to the defendant in the original proceedings. The Brussels regime would thus only apply to adversarial proceedings where the defendant had the possibility to make an appearance before the court. It is not necessary for both parties to have the opportunity to participate in the initial phase of the proceedings. The requirement of adversarial proceedings will be fulfilled if the parties have the possibility to launch an appeal and if they can participate in that procedure. ${ }^{41}$ Dutch Hoge Raad was therefore willing to enforce a German 'einstweilige Verfügung' as well as a 'Kostenfestsetzungsbeschluss' that had been ordered without hearing the defendant, but in the case where the defendant could challenge both decisions after the proper service of documents. ${ }^{42}$ The German Bundesgerichtshof appears to have taken a different approach. It refused in 2006 to enforce a Swedish arrestment which had been ordered without a preliminary hearing of the German defendant. ${ }^{43}$ In any case, proceedings where the defendant is not awarded the possibility to participate in the proceedings, which could result in a violation of the right to a fair hearing, are therefore automatically excluded from the facilitated recognition and enforcement procedure.

Aspects protected under art 6 (1) ECHR such as the requirements aimed at guaranteeing the effective participation of both parties in adversarial proceedings are therefore partly already safeguarded by the exclusion of judgments where the court does not decide an issue on its own authority or where one of the parties has no formal possibility to participate in the proceedings.

\footnotetext{
40 Case 125/79 Denilauler v SNC Couchet Frères [1980] ECR 1533. The question remains whether recognition may be possible under national law.

41 Case C-474/93 Hengst Import [1995] ECR I-2113, para 14; Case C-39/02 Maersk Olie \& Gas v Firma de Haan [2004] ECR I-9647, para 51.

42 Hoge Raad (7 November 2008) BD7584 (Realchemie). See also Hoge Raad (29 September 2006) AX3080 (B\&N Nordsjöfrakt and Northsea Shipping $v$ Westereems).

43 BGH (21 December 2006) IX ZB 150/05. The decision is criticised in the Heidelberg Report (see Hess, Pfeiffer and Schlosser (n 24)) 135.
} 


\section{Presence or representation in court: default of appearance and irre- gular service of documents initiating the procedure}

Art 34 (2) Brussels I recognises the fundamental importance of adversarial proceedings. A judgment given in default of appearance will only be recognised or enforced when the defendant was served with the document instituting the proceedings in a way to enable him to arrange for his defence. ${ }^{44}$ Art 34 (2) does not deal with the formal (im)possibility to participate in a proceeding, but rather relates to the effective (im)possibility. The service of documents which instituted the procedure enables the defendant to organise his defence before the foreign court. The ECJ has adopted an autonomous concept of default of appearance. Regardless of national procedural law, the ECJ will qualify a proceeding as default when it is initiated against a person without his knowledge, even when a lawyer was assigned to him. In such circumstances, the defendant remains powerless to defend himself, a defect that cannot be cured by a lawyer acting without his authority. ${ }^{45}$

Art 34 (2) is to be interpreted narrowly. The strict requirements for the refusal to recognise a judicial decision pronounced in another Member State is justified for two reasons. The first is to prevent procedural opportunism. A party should not be allowed to delay the procedure when he is aware that proceedings against him have been launched in another Member State and he is in a position to adequately prepare his defence. ${ }^{46}$ Relying in such circumstances on a procedural error would defeat the purpose of the provision.

The second reason is that the defendant is already protected at an earlier stage of the proceedings. Art 26 (1) Brussels I requires a court of its own motion to declare it has no jurisdiction when a defendant domiciled in one Member State is sued in a court of another Member State and does not enter an appearance, unless its jurisdiction is derived from Brussels I. Art 26 (2) requires the court to 'stay the proceedings so long as it is not shown that the defendant has been able to receive the document instituting the proceedings or an equivalent document in sufficient time to enable him to arrange for his defence, or that all necessary steps have been taken to this end.' A special regime is applicable when the document initiating the proceedings has been transmitted pursuant to Regulation $1348 / 2000$ on the service in the Member States of judicial and extrajudicial documents in civil or commercial matters. The Service Regulation

\footnotetext{
${ }_{44}$ The national procedural requirements for default in appearance are described in C Crifò, Cross-border Enforcement of Debts in the European Union: Default Judgments, Summary Judgments and Orders for Payment (Kluwer Law International, Deventer 2009) 151-254.

45 Case C-78/95 Hendrikman [1996] ECR I-4943.

Case C-183/90 Van Dalfsen and others $v$ Van Loon and Berendsen [1991] ECR I-04743.
} 
contributes to the safeguarding of the right of defence by establishing guarantees for a proper cross-border service of documents. Under art 19 of that Regulation, a judgment may not be given until the court has ascertained that either the document has been served in accordance with the procedural law of the Member State where the defendant is domiciled or that the document was actually delivered to the defendant or to his residence by another method provided for by the Service Regulation. In both circumstances, the service or delivery should have been effected in a manner to allow the defendant sufficient time to enable him to prepare a defence.

The Service Regulation itself is interpreted in the context of guaranteeing the effective participation of parties in adversarial proceedings. The document served should be drafted in the language of the Member State addressed or in a language that the defendant understands. ${ }^{47}$ The addressee cannot refuse to accept the document if it enables him to assert his rights in legal proceedings in the Member State of transmission. This is the case even where annexes are attached to the document instituting proceedings consisting of documentary evidence which is not in the language of the Member State addressed or in a language of the Member State of transmission which the addressee understands, but which has a purely evidential function and is not necessary for understanding the subject matter of the claim and the cause of action..$^{48}$

Art 34 (2) fulfils a complementary role to art 26. Firstly, the scope of art 34 (2) is broader since, unlike art 26, the former article is not limited to defendants domiciled in another Member State. Secondly, art 34 (2) allows the Member State in which recognition is sought to establish whether the document instituting the proceedings has been duly served according to its rules. Both the original court and the court before which recognition is sought thus have jurisdiction to determine whether the document instituting the proceedings has been properly served. ${ }^{49}$ In addition, art 34 (2) is interpreted in the light of the fair trial requirements. A defendant may not rely upon this ground for refusal to recognise a deci-

\footnotetext{
47 P Franzina, 'Translation Requirements under the EC Service Regulation: The Weiss und Partner Decision of the ECJ' (2008) X Ybk Private Intl L 565-577.

48 Case C-14/07 Weiss und Partner [2008] ECR I-3367.

49 Case 228/81 Pendy Plastic Products $v$ Pluspunkt Handelsgesellschaft [1982] ECR 2733. See, however, Corte Suprema di Cassazione (23 May 2008) 13425/2008 where the Italian Supreme Court held that the verification of whether the documents instituting the proceedings had been duly served had to be answered according to the law of the Member State of origin, and not the Member State where recognition is sought, provided that the procedure in the Member State of origin conforms to international public policy, in particular the right to a fair hearing.
} 
sion where he was notified of the elements of the claim, had the opportunity to arrange for his defence and has made an appearance before the original court..$^{50}$

The ECJ initially held that the document must necessarily be served before an enforceable judgment can be obtained against the defendant. The Court held explicitly that 'the possibility of having recourse, at a later stage, to a legal remedy against a judgment given in default of appearance, which has already become enforceable, cannot constitute an equally effective alternative to a defence in the proceedings before the first judgment is delivered'. ${ }^{51}$ Participation only at a later stage in the proceedings apparently caused a disadvantage to the defendant. Brussels I strikes a different balance. ${ }^{52}$ In contrast to the Brussels Convention, Brussels I prevents the refusal of recognition or enforcement when the defendant failed to commence proceedings to challenge the judgment when it was possible for him to do so. The inactive defendant is prevented from raising his absence in the proceedings at the stage of recognition and enforcement. The Greek Civil Supreme Court therefore held that the change of wording prevented a Greek company from invoking an irregular service of documents since the French judgment was delivered upon the company in Greece and the Greek company had the right to lodge an appeal within two months from the service of the judgment. ${ }^{53}$

Brussels I aims to strive towards the result that the check on the procedure is as far as possible performed in the Member State where the original proceedings took place. Brussels I perceives the possibility of obtaining a legal remedy as equivalent to the organisation of a defence at the beginning of the proceedings. ${ }^{54}$ Whether the reasoning holds water or not, it is not necessarily incompatible with the standards of art 6 ECHR which assess the proceedings as a whole. ${ }^{55}$ One might wonder whether the failure to lodge an appeal can be seen as an implicit waiver of the right to participate in the proceedings. In ASML Netherlands, the ECJ relied explicitly on the case law of the ECtHR to rule that the aim of simplifying the formalities with a view to their rapid and simple reco-

50 Case C-172/91 Sonntag [1993] ECR I-1963.

51 Case C-123/91 Minalmet [1992] ECR-5661, para 19.

52 G. Biagioni, 'Aspetti evolutivi nella disciplina comunitaria dell'esecuzione delle sentenze straniere: i regolamenti (CE) n 44/2001 e n 805/2004' in G Carella, Cooperazione giudiziaria ed efficacia delle sentenze: problematiche di diritto internazionale ed europeo (Cacucci Editore, Bari 2007) 199-213.

53 Aprios Пáyos (Greek Civil Supreme Court) (2 January 2009) 7/2009. In a similar vein, Dutch Hoge Raad (29 September 2006) AX3080; BGH (22 July 2004) IX ZB 2/03; BGH (12 December 2007) XII ZB 240/05.

54 Magnus \& Mankowski (n 20) 592.

55 In EU courts: Case C-341/04 Eurofood [2006] ECR I-3813. 
gnition and enforcement cannot be attained by undermining in any way the right to a fair hearing. In order for the defendant to have the opportunity to bring proceedings enabling him to assert his rights, he should be able to acquaint himself with the grounds of the default judgment in order to challenge them effectively. Mere knowledge of a judgment does not suffice. The defendant must have been aware of the contents of that decision, which presupposes that it was served on him. The defendant is not required to take additional steps that go beyond normal diligence in the defence of his rights, for example steps to become acquainted with the contents of the original judgment. Translation of the documents in a language that the defendant understands is necessary, ${ }^{56}$ although the defendant cannot invoke the failure to translate the document instituting the proceedings when he understands the legal nature of the document and ensures legal representation in the Member State of origin. ${ }^{57}$ The standard of art 6 is therefore incorporated in the notion 'possible'. It will only be possible for a defendant to have challenged the decision in the Member State of origin if he was in fact acquainted with its contents, because it was served on him in sufficient time to enable him to arrange for his defence before the courts of the State in which the judgment was given. ${ }^{58}$

The period of reasonable time starts to run when the notice has been served upon the defendant. The ECJ held in Klomps that the question of whether the defendant was left sufficient time to arrange for his defence was a factual appraisal of the circumstances of the case. ${ }^{59}$ The review in the Member State of origin that the documents instituting the proceedings had been duly served did not release the court in the Member State addressed from the duty to examine whether the defendant was afforded sufficient time and opportunity to arrange for his defence. The review of both the original court as well as the court addressed would make sense since the latter court is often in the best position to appreciate the factual circumstances surrounding the possibility of an individual domiciled in its territory to prepare a defence. The German Bundesgerichtshof held that the defendant had been afforded sufficient time to prepare his defence when the writ had been served upon him five days before the hearing, since a second hearing had been held five weeks later. ${ }^{60}$ In addition, the English Court of Appeal held five weeks to be sufficient time to prepare a

\footnotetext{
56 Case 305/88 Lancray SA v Peters und Sickert KG [1990] ECR I-2725.

57 Case C-420/07 Apostolides v Orams [2009] ECR I-0000. Note that at stake was the failure to translate the documents instituting the proceedings from Greek into English and not the final judgment.

58 Case C-283/05 ASML Netherlands [2006] ECR I-12041, para 49.

59 Case 166/80 Klomps [1981] ECR 1593.

60 BGH (6 October 2005) IX ZB 360/02.
} 
defence, even when the defendant was required to give notice of appearance within two weeks after being served the writ. ${ }^{61}$

\section{Public policy and the right to a fair trial}

Despite its numerical order, art 34 (1) Brussels I fulfils a residual function. It can only come into play when the other grounds for non-recognition or enforcement are not applicable. It is in principle for a Member State to decide which rules belong to its public policy. ${ }^{62}$ However, art 34 provides that a judgment shall not be recognised. A Member State is therefore bound not to recognise or enforce a foreign judgment whenever it is manifestly contrary to the public policy of that Member State. The framing of art 34 (1) in the wording of an obligation is slightly surprising. A Member State will not hesitate to refuse to recognise a decision when it manifestly violates its public order.

In the past decade, under the influence of Union law, public policy has moved away from being a purely national conception. ${ }^{63}$ Due to the division of competences between the Union and its Member States, economic and monetary provisions will constitute the core of that European public policy. ${ }^{64}$ The ECJ held in Eco Swiss that art 101 TFEU should be categorised as a matter of public policy, whose non-observance could lead to the setting aside of an arbitral award. ${ }^{65}$ The Court directly placed art 81 in the category of public policy within the meaning of the New York Convention on Arbitration (1958). The Court recalled that, unlike national judges in the courts of the Member States, arbitrators could not make a preliminary reference to Luxembourg. The same argument can be made with respect to judges in third countries. On the other hand, it is not sure whether competition law enters the conception of public policy in an intra Union situation. The Court held in Renault $v$ Maxicar that not every misapplication of Union law by another Member State would justify the resort to the public policy exception. Without entering into a discussion

\footnotetext{
${ }^{61}$ TSN Kunststoffrecycling GmbH $v$ Jurgens [2002] EWCA Civ 11.

62 R Moura Ramos, 'Public Policy in the Framework of the Brussels Convention' (2000) II Ybk Private Intl L, 25-39.

63 C Liebscher, 'Arbitral \& Judicial Decision: European Public Policy after Eco Swiss' (1999) 10 American Review of International Arbitration 81-94; J Basedow, 'Die Verselbständigung des europäischen ordre public' in M Coester, D Martiny and K Prinz von Sachsen Gessaphe (eds), Privatrecht in Europe, Festschrift für Hans Jürgen Sonnenberger (Verlag CH Beck, München 2004) 291-319 ; J Basedow, 'Recherches sur la formation de l'ordre public européen dans la jurisprudence' in Le droit international privé: esprit et méthodes. Mélanges en l'honneur de Paul Lagarde (Dalloz, Paris 2005) 55-74.

${ }^{64}$ G Karydis, 'Ordre public dans l'ordre juridique communautaire' (2002) 38 Revue Trimestrielle de Droit Européen 1, 12.

65 Case C-126/97 Eco Swiss [1999] ECR I-3055.
} 
whether art 102 TFEU had been correctly applied or not in French courts, the ECJ did not allow Italian courts to review the French decision. Renault $v$ Maxicar should be welcomed. With regard to Union law, it is the ECJ that enjoys the power of interpretation. It is not for Italian courts to verify the compliance of French courts with the TFEU. Member States should presume that the courts of another Member State have correctly applied Union law. Therefore, the dogmatic framework of the Treaties requires that a failure of France to comply with its obligations under Union law should be established by the ECJ and not by an Italian court.

Member States are, in the implementation of Union law, bound to comply with fundamental rights. ${ }^{66}$ The right to a fair trial has been recognised as a fundamental principle of Union law. ${ }^{67}$ It is beyond doubt that the recognition and enforcement of civil judgments pronounced in another Member State fall within the scope of Union law. The obligation would therefore also cover the public policy exception. The decision to enforce a judgment that has been pronounced in a Member State without observance of the guarantees of a fair trial does not constitute a separate infringement of Union law. The duty of compliance with the right to a fair trial applies only with respect to the enforcement proceedings themselves and not with the initial proceedings. Contrary to the wording of art 34, the application of the public policy exception remains a discretion of the Member States. Even when a breach with art 6 ECHR is manifest, art 34 (1) seems to allow, and not to require, the non-recognition of the original judgment. ${ }^{68}$ An obligation would be at odds with the principle of the free movement of judgments that requires that a defendant challenges the original decision principally and primarily in the Member State of origin. From the ECJ case law, it can be concluded that fundamental rights are used to cast light on the meaning of a private international law concept, but are not in themselves the source of obligation. ${ }^{69}$

The effects of Brussels I would be nullified if the free movement of judgments could be distorted by the wide use of the public policy exception. Union law therefore not only interferes positively in the public policy of Member States by introducing a Union minimum, but also negatively by imposing a maximum. The ECJ formulated in Krombach that in order

\footnotetext{
66 Case 260/89 Elliniki Radiophonia Tiléorassi (ERT) [1991] ECR I-2925; Case C-299/95 Kremzow [1997] ECR I-2629; Case C-309/96 Annibaldi $v$ Sindaco del Comune di Guidonia [1997] ECR I-7493; Case C-94/00 Roquette Frères [2002] ECR I-9011; Case C-276/01 Steffensen [2003] ECR I-3735.

67 Case C-185/95 P Baustahlgewebe $v$ Commission [1998] ECR I-8417; Joined Cases C-174/98 P and C-189/98 P Netherlands and Van der Wal v Commission [2000] ECR I-1; Case C-341/04 Eurofood [2006] ECR I-3813.

68 Case C-7/98 Krombach [2000] ECR I-1935, para 44.
} 
for the prohibition of any review of the foreign judgment as to its substance to be observed, the infringement would have to constitute a manifest breach of a rule of law regarded as essential in the legal order of the State in which enforcement is sought or of a right recognised as being fundamental within that legal order. ${ }^{70}$

Moreover, the relationship between the national courts is governed by mutual trust. ${ }^{11}$ It appears that the free movement of judgments would be frustrated if the courts of an enforcing State would be required to carry out a detailed review of whether the procedures in the Member State of origin had complied with art 6 ECHR. ${ }^{72}$ Restraint is therefore appropriate.

\section{Substantive public policy}

Although art 36 prohibits review of the substance of a decision, art 34 (1) has a substantive limb. ${ }^{73}$ The enforcement of a foreign decision might be manifestly contrary to the public policy of the state in which recognition is sought. The legal divergences between the Member States in the area of civil or commercial obligations will however rarely be that large to necessitate recourse to public policy. ${ }^{74}$

Another reason to trigger the application of substantive public policy would be when the original judgment has been obtained by fraud. However, since the recognising court is prevented from entering into an assessment regarding the merits of the judgment, this applies only to fraud that is discovered after the original judgment was rendered and when the defendant has no possibilities of challenging that judgment in the Member State of origin. The duty to challenge the original decision before the court initially seized does not apply when the new facts are beyond the control of those courts. The French Cour de Cassation thus refused to accept a plea of fraud since the defendant did not demonstrate that the factual incorrectness of the applicant's claim was unknown to

\footnotetext{
69 Fawcett (n 14) 24.

70 Case C-7/98 Krombach [2000] ECR I-1935, para 37.

71 Case C-116/02 Gasser [2003] ECR I-14693; Case C-159/02 Turner [2004] ECR I-3565; Case C-185/07 West Tankers [2009] ECR I-0000.

72 Maronier v Larmer [2002] EWCA Civ 774.

73 The German Bundesgerichtshof has accepted that enforcement can be refused when the disputed obligation has already been fulfilled. This is at daggers drawn with the prohibition as to review on the substance. BGH (14 March 2007) XII ZB 174/04. See critically B Hess, 'Die Unzulässigkeit materiellrechtlicher Einwendungen im Beschwerdeverfahren nach Art. 43 ff. EuGVVO' (2008) 28 IPRax 25-30.

74 Magnus \& Mankowski (n 20) 568.
} 
him during the original proceedings. ${ }^{75}$ It therefore appears that the German Bundesgerichtshof acted in breach of its obligations under Union law when it refused to enforce a Danish default judgment that took into account false submissions allegedly made by the applicant. The documents instituting the proceedings had been properly served upon the German defendant and the defendant should have attacked the factual incorrectness of the statements of the applicant in the Member State of origin and not in Germany. ${ }^{76}$

\section{Procedural public policy}

To return to the holding of the ECJ in Krombach, the Court recognises that the violation of the right to a fair hearing, as a fundamental right, can be manifestly contrary to the public policy of the Member State in which recognition is sought. Since art 34 (2) already provided safeguards as regard the proceedings in the Member State of origin, such a procedural limb of art 34 (1) was not obvious. ${ }^{77}$ Krombach concerned the death of a French national while residing in the holiday house of her stepfather, Krombach, in Germany. Despite repeated protests of Bamberski, the father of the deceased, the German public prosecutor did not press any criminal charges against Krombach, on the grounds that there was insufficient evidence of a criminal act. Bamberksi managed to trigger criminal proceedings in France and subsequently joined the criminal proceedings as a civil party. Risking being taking into custody, Krombach refused to appear before the French criminal court. Krombach was held to be in contempt of court and with regard to both the civil and the criminal proceedings prohibited from representation by a lawyer. Bamberski subsequently sought to enforce the civil judgment in Germany. The ECJ held that recourse to public policy is open in extreme cases where guarantees laid down in the Member State of origin and the ECHR have been insufficient to protect the defendant from a manifest breach of his right to defend himself before the courts of the Member State of origin. ${ }^{78}$ Hence,

75 Cour de Cassation, 29 January 2002. B. Ancel, 'Annotation to CdC 29 January 2002' (2002) 91 Revue Critique de Droit International Privé 573-577.

76 BGH (6 May 2004) IX ZB 43/03.

77 Magnus \& Mankowski (n 20) 574.

78 A Lowenfeld, 'Jurisdiction, Enforcement, Public Policy and Res Judicata: The Krombach Case' in T Einhorn and K Siehr (eds), International Cooperation Through Private International Law: Essays in Memory of Peter E Nygh, (TMC Asser Press, The Hague 2004) 229-248. The German refusal to extradite Krombach and the refusal to enforce the civil part of the French judgment did not ultimately benefit Krombach. In 2009, he was abducted from Germany and found tied up before a courthouse in Mulhouse (France). French authorities intend to re-open the criminal proceedings. See <http://conflictoflaws.net/2009/dr-krombachs-final-contribution-to-the-european-judicial-area> accessed on 7 March 2010. 
a mere difference between the two national laws is not enough. The laws of the Member State of origin must be at variance to an unacceptable degree with the legal order of the State in which enforcement is sought inasmuch as it infringes a fundamental principle.

Gambazzi concerned a Swiss lawyer working for a US undertaking. After the bankruptcy of the US undertaking, several creditors brought claims against a number of persons, including Gambazzi. The English court ordered Gambazzi to disclose information regarding his assets and also to submit certain documents relating to the main proceedings. Gambazzi unsuccessfully challenged the disclosure order on the grounds that the disclosure of some of the data requested would make him liable to criminal prosecution in Switzerland, and ultimately refused to comply. The English court held him in contempt of court and excluded him from the proceedings. Under English procedural law, the court will, in such circumstances, take over the claim of the applicants without entering into an analysis as to its merits. A default judgment was awarded against Gambazzi, of a sum approximately equivalent to EUR 300 million. The ECtHR declared Gambazzi's complaint to be manifestly ill founded. ${ }^{79}$ When confronted with an action for enforcement, the Milan Court of Appeals referred the question for a preliminary ruling to the ECJ. The ECJ held that it was for the court before which recognition is sought to establish whether the defendant had the opportunity to raise all the factual and legal issues which, in his view, could support his application and whether those issues were examined as to the merits, in full accordance with the adversarial principle, or whether, on the contrary, he was able to ask only limited questions. The ECJ left it to the national court to decide in the light of a comprehensive assessment of the proceedings and of all the circumstances as a whole whether the exclusion of a defendant from the proceedings on the grounds of non-compliance with a procedural order constituted a manifest and disproportionate infringement of the right to be heard. ${ }^{80}$

The enforcement of a foreign decision may in some circumstances be an obstacle to the right of access to justice. ${ }^{81}$ The national case law concerning art 34 (1) Brussels I has, however, mainly evolved around breaches of the right to a fair hearing that could, due its strict requirements, not be a ground for refusal under art 34 (2). For example, the Court of Appeal of England and Wales refused to enforce a Dutch judgment that had

\footnotetext{
79 G Cuniberti, 'Debarment from Defending, Default Judgments and Public Policy in Europe'(2009) University of Luxembourg Law Working Paper Series 2009-09, 8.

80 Case C-394/07 Gambazzi [2009] ECR I-0000.

81 H Meidanis, 'Three Greek Cases on the Brussels Convention' (2006) VIII Ybk Private Intl L, 281, 283.
} 
been delivered after the proceedings were revived by the applicant after twelve years of inactivity without informing the defendant. ${ }^{82}$ In its turn, the French Cour de Cassation refused to enforce an English judgment because neither the decision nor any other document stated any reasons on which the decision was based, but instead relied upon a rule of English procedure that exempts the court from stating reasons when it agrees with the substance of the applicant's claim. ${ }^{83}$ The Greek Civil Supreme Court refused to enforce an English determination of judicial expenses as it held the costs incurred to be excessive and disproportionate in relation to the value of the subject matter, in particular since they were more than 20,000 times higher than the judicial expenses would have been had the case been tried in Greece. ${ }^{84}$ In addition, an incorrect translation of the method and periods of limitation to lodge an appeal in the Member State of origin could prevent recognition if it amounted to depriving the defendant of the opportunity to defend himself in the Member State of origin. ${ }^{85}$

The ECJ has provided Member States with a certain margin of appreciation to establish whether the proceedings before the original court have been in conformity with the right to a fair hearing. The additional check over the procedure is, even in the common European justice area, justifiable. Cross-border disputes are, due to differences in language, procedures for the service of document, geographical distance and unfamiliarity with the procedures before the original court, far more likely to impact upon the right to a fair hearing. The ECJ itself seems to have recognised that, with regard to weaker parties, the geographical distance as such may be an obstacle to the effective enforcement of civil rights. ${ }^{80}$ Although national courts have only made restrictive use of public policy, ${ }^{87}$

82 Maronier v Larmer [2002] EWCA Civ 774. X Kramer, 'Enforcement under the Brussels Convention: Procedural Public Policy and the Influence of Article 6 ECHR' (2003) Intl Lis 16-20.

83 Cour de Cassation (22 October 2008) 06-15577. See also Cour de Cassation (17 January 2006) 03-14483 where the CdC held that French courts had a certain margin in establishing whether the duty to state reasons had been complied with. Even though the judgment itself did not state reasons, the requirement was complied with when the applicant in the attachment to the original judgment produced the original writ of summons and the parties' submission, including a submission from the defendants' CEO acknowledging the existence of a debt.

84 'Apeı́os Пáyos (17 November 2006) 1829/2006.

85 Sad Najwyzszy Rzeczypospolitej Polskiej (Polish Supreme Court) (28 March 2007) II CSK $533 / 2006$. Note that the case was not decided under Brussels I, but under a similar provision in the Lugano Convention.

86 Joined Cases C-240/98 to C-244/98 Océano [2000] ECR I-4941; Case C-168/05 Mostaza Claro [2006] ECR I-10421; Case C-243/08 Pannon [2009] ECR I-0000; Case C-40/08 Asturcom [2009] ECR I-0000.

87 Sad Najwyzszy Rzeczypospolitej Polskiej (21 March 2007) I CSK 434/06 (dismissal of appeal due to absence of the appellant at hearing); Banco Nacional de Comercio (11 October 2007) EWHC 2322; BGH (17 June 2009) XII ZB 82/09 (Grant of retrospective child support 
the cases discussed above have demonstrated that an additional check for compliance with the right to a fair trial remains necessary. Not only have the procedural laws of the Member States yet to converge to a degree that would preclude a decision from one Member State infringing a fundamental principle in another Member State, cross-border litigation may by definition already put a strain on the right of a defendant to effectively participate in the proceedings.

\section{Art 6 ECHR and the free movement of judgments}

The ECJ draws inspiration from art 6 ECHR when interpreting Brussels I. That influence goes beyond the verification of compliance with the right to a fair trial under the heading of public policy. In some circumstances, violation of the right to a fair trial would have as a consequence that the decision does not benefit from the free movement of judgments since the decision will not qualify as a 'judgment' for the purpose of Brussels I. In other circumstances, the absence of one of the parties during the original proceedings may constitute grounds for non-recognition, while public policy may be used to combat the remaining violations of the right to a fair trial. Fundamental rights have been used to give shape to PIL concepts, but not as an autonomous source of obligations as such. The ECJ differs in this respect from the ECtHR, which in Pelligrini required on the basis of the Convention the non-enforcement of a judgment rendered in a non-Contracting State in violation of art 6 ECHR.

Art 6 ECHR only imposes minimum standards. Art 47 of the Charter of Fundamental Rights of the European Union ${ }^{88}$ has codified the right to a fair trial in the constitutional architecture of the Union. Although the Charter is addressed only to the institutions, it may prove to be a useful guiding tool. The text of the EU Charter goes further than art 6 ECHR in that it explicitly protects the possibility of being advised, defended and represented, as well as the right to legal aid for those who lack sufficient resources in so far as such aid is necessary to ensure effective access to justice. In addition, cases such as Gambazzi, where the ECtHR found the allegation to be manifestly ill founded, but the ECJ did not preclude Italy from refusing the English judgment on the grounds that it contravened Italian public policy since the English judge had failed to observe the requirements of a fair trial as interpreted in Italy, suggest that the

\footnotetext{
under conditions not permissible in Germany; exclusion of review as to the merits of the original decision); French Cour de Cassation (14 October 2009) 08-14489 (service of original judgment upon legal representation in the Member State of origin, instead of upon the defendant).

${ }^{88}$ Art 6 (1) TFEU attributes to the Charter of Fundamental Rights the same legal value as the Treaties.
} 
EU affords in general higher protection of the right to a fair trial than the jurisprudence of the ECtHR.

In its Green Paper on the revision of Brussels I, the European Commission proposed to abolish the exequatur completely. ${ }^{89}$ The deletion of any administrative check in the country where recognition is sought would mean that Member States, as soon as the judicial decision qualifies as a judgment within the scope of the Regulation, does not have any means to refuse the recognition or enforcement of a decision not rendered in conformity with the right to a fair trial. The Commission aims to reduce the intermediate measures which are still necessary to enable the recognition and enforcement of a judgment. The enforcement of civil judgments still requires a lot of time and resources. The Heidelberg Report on the application of Brussels I indeed provides ground to question the exequatur. In Hungary, an exequatur can be obtained by the applicant in a couple of hours provided he provides all the necessary documents, but the procedure can take up to seven months in Greece. ${ }^{90}$ Such long delays in enforcement are in themselves questionable in the light of the right to a fair trial. The concerns apply with more force given that an exequatur is nearly never challenged and, even when challenged, applications are rarely successful.

The Commission draws attention to the Regulation creating a European Enforcement Order for Uncontested Claims. The European Enforcement order abolishes the exequatur completely and replaces it by a control in the Member State of origin. ${ }^{91}$ The regulation itself sets out procedural safeguards for the service of documents, and a special review should remedy extraordinary situations where the defendant was not served personally in a manner that amounted to a deprivation of the right to arrange for his defence or where he could not object to the claim by reason of force majeur. ${ }^{92}$ Refusal of enforcement in the Member State addressed is still possible in the event of an irreconcilable, earlier judgment. ${ }^{93}$ However, the right to a fair trial encompasses more than the due service of documents affording the defendant the possibility to prepare a defence. One has to recall only art $47 \mathrm{EU}$ Charter that guarantees access to legal aid for those who lack sufficient resources. In the area of uncontested claims, concerns of fundamental rights will play a smaller role since the defendant concedes the existence of a claim. Requirements aimed at protecting the adversarial nature of a trial will not be violated if

\footnotetext{
89 Green Paper on the Review of Council Regulation (EC) no 44/2001 on Jurisdiction and the Recognition and Enforcement of Judgments in Civil and Commercial Matters COM (2009) 175 final.

90 Hess, Pfeiffer and Schlosser (n 24) 130-131.

91 Crifò (n 44) 61-102.
} 
the defendant does not seek to contest the substance of the claim of the applicant.

Regulation 4/2009 on jurisdiction, applicable law, recognition and enforcement of decisions and co-operation in matters relating to maintenance obligations abolishes the exequatur in both contested and uncontested claims for Member States that have ratified the 2007 Protocol to the Hague Convention on the Law Applicable to Maintenance Obligations. The regulation provides procedural guarantees for the service of documents but also for the right to legal aid. The protection of the rights of defence is guaranteed via a special procedure that may challenge the judgment in the Member State of origin. The Commission justified the absence of the exequatur on the grounds of the small number of problematic judgments, the possibility of review a posteriori, the protection of the rights of defence and the harmonisation of the rules to determine the applicable law. The a posteriori review clause does not contain any express reference to public policy. The argument that uniform rules exist in determining the applicable law does not convince as a reason for the deletion of public policy since it cannot be excluded that the law that is identified by the common rules violates a fundamental principle of another Member State. Nevertheless, the abolition of the exequatur in Regulation 4/2009 appears to be a fact. The Union ratified the Protocol on behalf of all Member States, save Denmark and the United Kingdom, on 8 April 2010.94 The Protocol has not entered into force yet, but the Union has made a unilateral declaration stipulating it will provisionally apply the Protocol from 18 June 2011, which will coincide with the date of application of Regulation 4/2009. ${ }^{95}$

As the ECJ has consistently held, Brussels I aims to strike a fair balance between the free movement of judgments and the protection of the right to be able to conduct a proper defence. ${ }^{96}$ The right to a fair trial should not be sacrificed on the altar of administrative efficiency. The right to a fair trial is not only guaranteed via procedural law, but is derived from the context of the legal system as a whole. National rules outside procedural law can interfere with the ability to prepare a proper defence. Gam-

\footnotetext{
92 Art 12-19 Regulation (EC) No 805/2004 creating a European Enforcement Order for Uncontested Claims.

93 Art 21 European Enforcement Order.

94 Council Decision 2009/941 on the conclusion by the European Community of the Hague Protocol of 23 November 2007 on the Law Applicable to Maintenance Obligations.

95 The declaration is accessible on the website of the Hague Conference on Private International Law <http://www.hcch.net/index_en.php?act=status.comment\&csid=1065\&disp=resdn> accessed on 20 May 2010.
}

96 Case 49/84 Debaecker v Plouvier [1985] ECR 1779. 
bazzi invoked the possibility of criminal prosecution under Swiss law as justification for the refusal to comply with an English procedural order. It is exactly these disturbances between the co-ordination of laws that make the public policy of the Member State addressed a useful tool. An exclusive control in the Member State of origin, even when accompanied with minimum standards, ${ }^{97}$ is inadequate. In the light of the large majority of enforcement orders that are executed without a challenge, and the small possibility of successfully challenging a foreign decision, it would make sense to reconsider the exequatur. Foreign judgments would have the same force as national judgments and private parties would be spared the burden of having to apply for an exequatur. The numerous national and ECJ cases discussed have demonstrated that despite uniform rules relating to jurisdiction, applicable law and the common minimum safeguard of art 6 ECHR judgments pronounced in one Member State can still manifestly shock the public order of another Member State. A possibility for review, even merely a posteriori, should therefore remain in the Member State addressed, and not only before the court originally seized.

The gradual simplification of the requirements to execute a judgment pronounced in another Member State reflects the deepening European integration. Nevertheless, the ECJ has continued to place emphasis on the right to a fair hearing, in particular the right to be able to effectively prepare a defence. The ECJ seems in its case law to provide for a higher level of protection of the right to a fair hearing than the ECtHR. It is doubtful whether the elimination of the exequatur and the impossibility of any review in the Member State addressed is compatible with the high level of protection of the right to a fair trial that the ECJ has developed in its case law..$^{98}$ One only has to recall a case like Klomps where a decision of the court in the Member State of origin that documents instituting the proceedings duly served upon the defendant did not release the court in the Member State addressed from the duty, which implied an appraisal of factual circumstances, to verify whether the documents were served in such a way as to enable him to arrange for his defence. ${ }^{99}$ The complexity of trans-border litigation as well as the sometimes hampering co-ordination between the legal systems of the Member States would justify control

\footnotetext{
97 A Borrás, 'Le droit international privé communautaire: réalités, problèmes et perspectives d'avenir' (2005) 317 Recueil des Cours 323, 453.

98 P Schlosser, 'The Abolition of Exequatur Proceedings - Including Public Policy Review' (2010) 2 IPRax 101-104; P Beaumont and M Johnston, 'Abolition of Exequatur in Brussels I: Is a Public Policy Defence Necessary for the Protection of Human Rights?' (2010) 2 IPRax 105-110.

99 Case $166 / 80$ Klomps, para 15 . Note, however, that this statement was made in the context of art 27 (2) Brussels Convention (art 34 (2) Brussels I), which would be deleted if the exequatur were abolished.
} 
over the foreign decision. The free movement of judgments would in such circumstances not work fundamentally differently from the free movement of goods or services. In the context of art 34 TFEU, it is also for the Member State of origin to determine whether goods have been lawfully produced, but the free circulation of goods may under certain conditions be refused by the host Member State on the basis of public policy considerations. With regard to the free movement of services, the ECJ held in Omega that the perception of public policy evolves over time and differs from Member State to Member State. ${ }^{100}$ What may shock the public order in Germany may be acceptable in the United Kingdom. This statement is not only true with regard to services or goods, but could also have been said about the free movement of judgments. This applies even more tenaciously when public policy in the context of the free movement of judgments has been used to safeguard a fundamental right. In the light of the strain that administrative expediency may place upon the protection of the right to a fair trial, one should be wary about taking the free movement of judgments beyond the free movement of goods and services.

\section{Conclusion}

Brussels I maintains a very liberal regime for the recognition and enforcement of foreign decisions. To counterbalance the limited possibilities for Member States not to give effect to judicial decisions, due regard should be given to the requirements of a fair trial. A fair balance should be struck between the free movement of judgments in civil and commercial cases and the protection of the rights of defence. Art 6 ECHR provides procedural minimum standards that have been used in the ECJ case law as a useful guiding tool.

In Pellegrini, the ECtHR held that when a Contracting State is confronted with a judicial decision from a non-Contracting State, the national court is under the obligation to duly satisfy that the original proceedings fulfilled the guarantees of art 6 ECHR. The judgment is most likely limited to a judicial decision originating in a non-Contracting State since it can be presumed that a judgment rendered in a Contracting State complies with the standards of art 6. Moreover, a private party can lodge a complaint to the ECtHR. The question of refusal of recognition or enforcement is a matter left to the public policy of the Contracting States.

The standards of art. 6 merely function as a minimum. The ECJ has used the right to a fair trial as a guiding tool in its case law. The right to a fair trial sheds light on notions of PIL instead of being an autonomous source of obligations. The approach of the ECJ differs in this respect from

100 Case C-36/02 Omega Spielhallen [2004] ECR I-9609. 
the attitude of the ECtHR in Pelligrini. The case law of the Court generally offers a higher level of protection than art 6 ECHR. The ECJ has not limited the right to a fair hearing to public policy. It held that the liberal system of recognition and enforcement required that a defendant should be able to submit every point of law that he deems to be relevant. Not every judicial decision will therefore qualify as a judgment. The effective participation of both parties in adversarial proceedings and the institutional independence of the court are therefore already partly safeguarded by the exclusion of judgments where the court does not decide an issue on its own authority or where one of the parties has no possibility to participate in the proceedings.

Of significant importance is art 34 (2) that safeguards the right to an adversarial proceeding by providing as ground for non-recognition the failure to duly serve the documents instituting the proceedings in a manner allowing the defendant the effective possibility to prepare his defence. Art 34 (2) does not protect the passive defendant. The possibility to invoke the irregular service of documents is forfeited when the defendant failed to commence proceedings to challenge the judgment in the Member State of origin when it was possible for him to do so. The fact that the court of origin ruled that the defendant was afforded an effective possibility to prepare his defence does not relieve the Member State addressed from the duty to conduct the same analysis. That exception to the general principle of the free movement of judgments is justified since the analysis is often a factual appraisal where the Member State addressed may be in a better position to fully appreciate the factual circumstances than the Member State of origin.

Public policy can be used as a tool of last resort. The national court is however prohibited from reviewing the merits of the case. The test of public policy would otherwise create an additional possibility of appeal. The infringement of the public policy of a Member State in which enforcement is sought would have to constitute a manifest breach of a rule of law regarded as essential in the forum or of a right recognised as being fundamental within that legal order. A Member State thus may review compliance of the right to a fair trial under the heading public policy. Instead of giving direct application, fundamental rights are subsumed in a PIL doctrine. However, the mere fact that the court of origin protects the right to a fair trial in a different manner, or strikes a different balance, is not enough. An example of a manifest breach of a fundamental rule is the exclusion of participation or legal representation in a civil proceeding connected to a criminal action when the defendant fails to make an appearance in the criminal proceedings because he runs the risk of being deprived of his liberty.

The proposal of the Commission to abolish the exequatur should 
therefore not be unconditionally embraced. Substantial differences remain between national procedures and applicable standards of the right to a fair trial. The complexity of transnational litigation as a result of differences in procedure and language may in itself already raise concerns about fair trial. However, since the exequatur is 19 times out of 20 not challenged, good reasons exist to consider its abolishment. An ex posteriori review on the initiative of the defendant might be a middle way. As the numerous cases analysed have demonstrated, the right to a fair trial can only be effectively guaranteed when such control can be conducted in the country where recognition is sought. 